\title{
TAXONOMIC NOTES ON SEMPERVIVUM ARMENUM BOISS. \& A. HUET (CRASSULACEAE) FROM TURKEY WITH AN AMENDED DESCRIPTION
}

\author{
Fergan Karaer and Ferhat Celep* \\ Department of Biology, Ondokuz Mayls University, Kurupelit, Samsun, Turkey
}

Key words: Sempervivum armenum, Taxonomic notes, Amended description, Turkey

\begin{abstract}
Abstact
As a part of a revision of the genus Sempervivum L. in Turkey S. armenum Boiss. \& A. Huet var. armenum and var. insigne Muirhead, are better treated at the rank of subspecies based on over 150 specimens. Moreover, an amended and expanded description, distribution, phenology, ecology of these subspecies are provided. With respect to IUCN categories, subsp. insigne has been assessed as vulnarable.
\end{abstract}

The genus Sempervivum L. (Crassulaceae) comprises about 50 species and 17 hybrids throughout the world. It is mainly distributed in mountainous regions of central and southern Europe, southwestern Asia, Caucasia and the Mediterranean (Topalov et al. 2006). The species $S$. armenum Boiss. et A. Huet. was reduced to synonym under S. globiferum L. by Boissier (1872). This has resulted in continued confusion on Turkish Sempervivum. Wale (1942) concluded that $S$. armenum is distinct from any European species. The first revision of Sempervivum in Turkey was done by Muirhead (1972) in which she recognized 11 species and 2 varieties. Since the publication of the flora, three more species, one subspecies, one hybrid and one new record have been described from Turkey (Davis et al. 1988, Karaer et al. 2010, Neeff 2005).

Since 1999, as a part of a revisional study of the genus Sempervivum in Turkey, the first author has carried out extensive field studies (Fig. 1) and collected a large number of specimens (about 2500 specimens) and preserved them at the Biology Department, Ondokuz Mayis University.

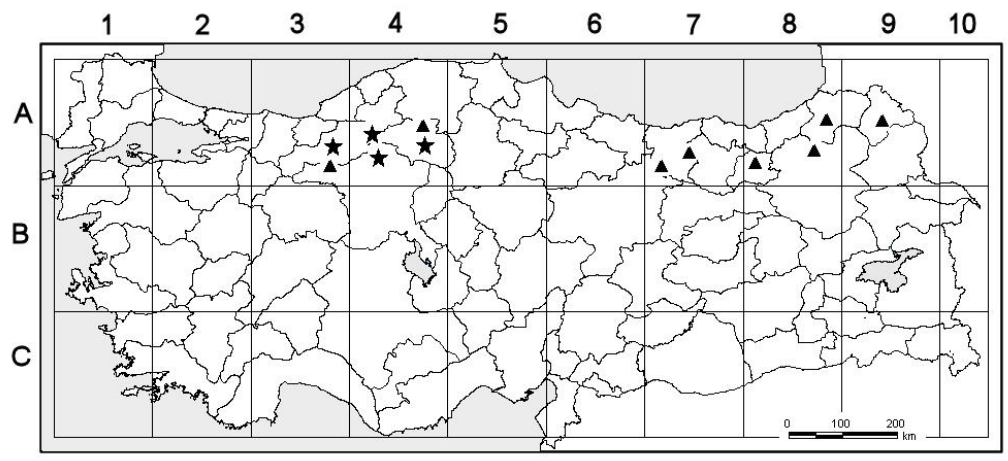

Fig. 1. Distribution map of Sempervivum armenum, subsp. armenum ( $\mathbf{\Lambda})$ and subsp. insigne ( $\star$ ) in Turkey.

After extensive field and herbarium studies, present authors have reached the conclusion that these S. armenum var. armenum and var. insigne, have many and consistent morphological (Table 1), ecological and geographical differences that they think these two varieties should be recognized as subspecies, i. e. S. armenum Boiss \& A. Huet subsp. armenum and S. armenum Boiss \& A. Huet and subsp. insigne (Muirhead) F. Karaer.

*Corresponding author: Department of Biological Sciences, Middle East Technical University, 06530, Ankara-Turkey.E-mail: fcelep@metu.edu.tr, ferhat_celep@hotmail.com 
Table 1. Main morphological differences between subspecies of Sempervivum armenum.

\begin{tabular}{lll}
\hline Parameters & Subsp. armenum & Subsp. insigne \\
\hline Rosettes in diameter $(\mathrm{cm})$ & $4-8$ & $2-3(-4)$ \\
Stem length $(\mathrm{cm})$ & $20-25$ & $9-18(-20)$ \\
Stem/leaves colour & Purple & Pale rose \\
Flowers number & $30-50$ & $15-25(-30$ \\
Flowers diameter $(\mathrm{cm})$ & $21-28$ & $16-20$ \\
Calyx tip & Purple & Green (rarely purple dots) \\
Filament colour & Pale lavender & Violet \\
\hline
\end{tabular}

Sempervivum armenum Boiss. \& Huet subsp. armenum, in Boiss., Diagn. Ser. 2(2): 60 (1856). Synonyms: S. braunii Ledep. var. glabrum Medw., Pl. Caucasus: 169 (1915). = S. armenum var. armenum, Ic: Notes R.B.G. Edinb. 29: t. 1 A f. 1 (1969).

Type: Inter Bayburt et Erzurum, in valle Kassaklu, August 1853, A. Huet (iso. K!).

Perennial, $20-30 \mathrm{~cm}$, up to $35 \mathrm{~cm}$ tall when in flower. Rosettes $4-8 \mathrm{~cm}$ in diameter; leaves oblanceolate-spathulate, ovate-lanceolate to spathulate, $30-50 \times 9-11 \mathrm{~mm}$, mucronate, young rosettes leaves with a few scattered glands but when mature glabrous, glaucous with dark purple tip, margin strongly pectinate-ciliate, ciliae c. $1 \mathrm{~mm}$ long, cauline leaves lanceolate, glandular hairy, $30-47(-52) \times 10-12(-15) \mathrm{mm}$, short pubescent hairy at the base or rarely glabrous, purple, imbricate, scape c. 7 - $9 \mathrm{~mm}$ in diameter. Inflorescence $30-50$ (-60) flowered, narrowly scorpioid cymose, with 3 - 5 branches, branches $5-10 \mathrm{~cm}$ long; bracts linear, up to $15 \times 5 \mathrm{~mm}$, green to pale rose, glandular hairy. Flowers c. $21-28(-33) \mathrm{mm}$ in diameter, pedicels $1-3 \mathrm{~mm}$ long, calyx lobes lanceolate, acute, $3-3.5 \times 1.5 \mathrm{~mm}$, tip dark purple, densely glandular; (12) 14 17 merous; petals linear-lanceolate, $9-11 \times 1.5 \mathrm{~mm}$, densely glandular, pale yellow or greenish, purplish towards the base. Stamens (24-) 28 - 34, filaments pale lavender, hairy at base. Carpels glandular hairy; scales erect, subquadrate-rotund.

Sempervivum armenum Boiss. \& Huet subsp. insigne (Muirhead) F. Karaer stat. nov.

Basionym: Sempervivum armenum Boiss. \& Huet var. insigne Muirhead in Notes R.B.G. Edinb. 29: 19 (1969).

Type: Ankara: near Kızılcahamam, c. 1200 m, 22 July 1956, McNeill 284 (holo. E!, cult. E!).

Subsp. insigne differs from subsp. armenum because of its smaller rosettes $2-3(-4) \mathrm{cm}$ in diameter and smaller basal leaves $(20-29 \times 7-9 \mathrm{~mm})$, smaller scape length $(9-18(-20) \mathrm{cm}$ when in flower, its pale rose and $15-30(-35) \times(5) 7-9 \mathrm{~mm}$ cauline leaves. As well as, its inflorescence (10) 15 - 30 (-35) flowered, flowers smaller in diameter size, calyx tip green (rarely purple dots) and filaments violet.

Subsp. insigne is a local endemic. It is distributed only North-West Anatolia. However, subsp. armenum is distributed in North-East Anatolia and rarely distributed in North-West Anatolia they occupy their own habitat although sometimes they overlap. This situation could make gene exchange between subspecies feasible and interspecific hybridisation occurs in these places. $S$. armenum subsp. insigne was probably formed by means of sympatric speciation from subsp. armenum. With respect to morphological relationships of these two subspecies and their distribution pattern, there is a possibility that subsp. armenum is the ancestral to subsp. insigne. The collection sites are within the Euro-Siberian phytogeographic region and the locality has a relatively humid climate. In Turkey, distribution of the subsp. armenum shows interruption in the 
central Black Sea region. It appears believe that there are some climatic, edaphic, geologic and geomorphologic differences that give rise to this interruption.

For the first time, the conservation status of $S$. armenum subsp. armenum and subsp. insigne was assessed as LR (Lower Risk) in Turkish Red Data Book (Ekim et al. 2000). According to authors recent field surveys and IUCN criteria (IUCN 2001), S. armenum subsp. insigne has been assessed as VU (Vulnerable) because of its local existence and small population size, and subsp. armenum has been assessed as LC (Least Concern) because of its distribution patterns and population size.

\section{Acknowledgements}

The authors thank Dr. Urs Eggli for providing useful discussions. Thanks are due to the Sibbald Trust (Royal Botanic Garden, Edinburgh) for financial support to the first author's visit to Edinburgh during 2004-2005, to the Curators of the herbaria Edinburg (E), Kew (K), Gazi University (GAZI), Hacettepe University (HUB), Ankara University (ANK), Ondokuz Mayıs University, Biology (OMUB), Istanbul University (ISTE) and Selcuk University (KNYA) for allowing to study their Sempervivum collections, and the Scientific and Technical Research Council of Turkey (TUBITAK Project No. TBAG-1747) for financial assistance.

\section{References}

Boissier E. 1872. Flora Orientalis - Genevae et Basileae. Apud H. Georg, Lugundi.

Davis P.H., R.R. Mill and K. Tan. 1988. Sempervivum L. In: Flora of Turkey and East Aegean Islands (Supplement I.). Vol. 10, P.H. Davis, R.R. Mill and K. Tan (Eds). Edinburgh Univ. Press, Edinburgh.

Ekim T., M. Koyuncu, H. Duman, Z. Aytaç and N. Adıgüzel. 2000. Red data book of turkish plants (Pteridophyta and Spermatophyta). Barışcan Ofset, Ankara.

IUCN. 2001. IUCN Red List Categories: Version 3.1. pp. 1-23. Prepared by the IUCN Species Survival Commission. IUCN, Gland and Cambridge.

Karaer F. and F. Celep. 2008. Sempervivum ekimii nom. et stat. nov. for S. minus var. glabrum (Crassulaceae), with an amplified description. Ann. Bot. Fennici 45: 229-232.

Karaer F., F. Celep and H.G. Kutbay. 2010. Morphological, ecological and palynological studies on Sempervivum sosnowskyi Ter-Chatsch. (Crassulaceae) with a new distribution record from Turkey. Aust. J. Crop (in press).

Mitchell P.J. 1974. Turkish Sempervivums. J. Sempervivum Soc. 5(4): 2-6.

Muirhead C.W. 1969. Turkish species of Sempervivum L. Notes Bot. Gard. Edinb. 29: 15-28.

Muirhead C.W. 1972. Sempervivum L. In: Flora of Turkey and East Aegean Islands. Vol. 4, P.H. Davis (Ed.), pp. 209-248. Edinburgh Univ. Press, Edinburgh.

Neeff P. 2005. Neue Taxa der Gattung Sempervivum (Crassulaceae) in der Türkei. Kakteen und andere Sukkulenten 56(3): 71-72.

Topalov K., M.E. Mort, P. Neeff, D. Lakusic and B. Zlatkovic. 2006. Preliminary phylogenetic analyses of Sempervivum L. (Crassulaceae) inferred from DNA sequence data. In: Abstract, pp 300. Botany 2006 Conference, California State Univ. Press, Chico.

Wale R.S. 1942. Anatolian Semperviva. Bull. Alp. Gard. Soc. 10: 233-241. 